\title{
Hosts' Perception of Impacts of Community Development Schemes and Tourism Projects In Southeast Nigeria
}

\author{
Matthias U. Agboeze \\ Department of Adult Education and Extra-Mural Studies, University of Nigeria, Nsukka, Nigeria \\ Email: matthias.agboeze@unn.edu.ng \\ Elochukwu A. Nwankwo \\ Department of Archaeology and Tourism, University of Nigeria, Nsukka \\ Email: elochukwu.nwankwo@unn.edu.ng
}

Doi:10.5901/mjss.2016.v7n5p361

Abstract

Recently, community development schemes and tourism projects at rural communities have not been sustainable due to their perceived impacts by members of the host communities. This study conducted ethnographic investigations in five selected lgbo communities in Southeast Nigeria, to examine hosts' perception of impacts of community development schemes and tourism projects. The study which lasted between 2011 and 2014 was able to find out some of these perceived impacts coupled with the consequences of hosts' perceptions. The result has the potentialities of addressing these problems to maximize the gains of these project initiatives to the development of rural communities.

Keywords: Community development schemes, tourism projects, perception, impacts, development projects, host community.

\section{Introduction}

Community development's schemes have been perceived as initiatives aimed at improving the lives of those living in the rural areas. It is seen as one of the instruments for uplifting the living standard of those in the rural areas (Anyanwu 1992; Eze 1990). It is also seen as the "...development or improvement in the quality of life of the people in a community" (Imhabekhai 2009:1). In most cases these rural communities are given the opportunity to decide on a particular scheme they want through the principle of Felt-Needs in community development. This could be said to have helped in the past in ensuring that projects that are purposeful and meaningful are sited at these rural communities (Eze 1990). Such initiatives could be on improving the standard of formal or informal education, provision of public power supply, provision of health facilities, loan facilities, provision of alternative and more common source of water, establishment of cooperative societies, provision of agricultural facilities, road construction and maintenance, community bank project, market construction, post office project and other entrepreneurial opportunities (Eze 1990; Anyanwu 1992; Hayton 1995; Imhabekhai 2009; Abiona 2009; Nwankwo \& Agboeze 2014). Records have revealed that provision of community development schemes at rural communities have the potentialities of discouraging rural-urban migration which is a threat to balanced-economic growth and carrying capacity of urban centers (Okonkwo 1995; Abiona 2009; Ezeani 1995). However, Tourism development has been discovered as one of the avenues for harnessing some of the resources of rural communities for meaningful socio-economic development (Hampton 2005; McKercher and du Cros 2002). It is the harnessing of various tourism potentialities of a place to socio-economic development. Tourism resources which are the major stimulators of tourism development in a place are grossly found in the Southeast Nigeria as noted by Oformata and Okafor (2002) in the following lines;

In Igboland, the major elements which constitute the physical resources of tourism are the landforms, river bodies and banks, lakes, forests and wildlife. Most of these resources are yet in their raw state awaiting further development. This stage of development notwithstanding, these physical tourist resources engages sightseers from within and outside Igboland (Oformata \& Okafor 2002:618).

Community development schemes and tourism development projects are amongst the backbones of sustainable development in the rural areas, and have been identified as amongst the basic needs of rural communities for a sustainable lifestyle. This is based on the fact that it seeks "to have potential as a unifying framework for tackling the 
various problems of poverty, environmental degradation and human misery in developing countries including Nigeria" (Eboh 1995:3). Also Agbor (2013) listed some other challenges of rural communities as environmental degradation, poor health condition, absence of minimal infrastructure, poverty, and restiveness, which these two concepts can offer solutions to. Agboeze and Nwankwo (2013:85) noted that;

Indigenous communities have fallen victims of underdevelopment arising from the remote nature of their environment coupled with public/private concentration in the urban areas for meaningful infrastructural and super structural development. This situation has deprived most of these indigenous communities in Nigeria the opportunities of unleashing their potentials and maximum utilization of their human and non-human resources for socio-economic development in their environment.

Moreover, the articulate provision of felt-needs and harnessing of tourism resources have been identified as a perfect synergy for sustainable socio-economic growth of rural communities with less impact on traditional values. The present understanding of these projects is revealing some areas of conflicts for these projects in the rural areas of Southeast Nigeria. In some cases "...policy makers and practitioners, once those projects take off and are effectively managed, the governmental responsibility of providing for the welfare of the population is felt to have been accomplished. Effort is hardly made to follow implementation with search for possible social obstacles to programme success" (Ukaegbu \& Agunwamba 1995:42-43). Some previous studies have deeply discussed the importance of synergy of these two concepts in sustainable socio-economic development of rural communities (Nwankwo \& Agboeze 2014; Osefoh \&Agbonome 2014; Ezeh1990; Abiona 2009) with less emphasis on the possible negative impacts of such programs both to the host communities and sustainability of such projects. "Little or no attention is paid to the possible effects of social relationships within target populations; or between a target community and neighbouring communities; or still, between two or more target communities" (Ukaegbu \& Agunwanba 1995:43), both during pre-project, project and post- project feasibility studies of the program. Sometimes hostilities are switched towards these initiatives by the host due to perceived threats. This has raised critical questions on the relevance and acceptance of community development schemes and tourism projects by host communities. For instance, what are these impacts as perceived by these hosts? What are the resultant effects of these impacts? However, this study intended to ascertain the nature of hosts' perceived impacts of community development schemes and tourism projects in the five investigated communities and the resultant effects of these impacts. This would aid in repositioning community development schemes and tourism projects in the socio-economic development map of rural communities in Nigeria and other developing nations.

\section{Study Methods}

Studies on the impacts of development projects from the perception of the host community have been notable on two distinctive approaches; synchronic and diachronic (Silva 2014). Synchronic which is the most common used (see Aguilo and Rosello 2005; Besculides Lee, and McCormick, 2002; Jimura 2011; in Silva 2014) has limitations on understanding the dynamics of development projects.

This study majorly made use of ethnographic field research carried out between 2011 and 2014. Three weeks in 2011, five weeks in 2012, two weeks in 2013 and one week in 2014. This was distributed amongst the systematically selected sample communities. These communities were selected from the Southeast Nigeria with the aid of cluster and purposive sample techniques respectively. During these ethnographies, the researchers who were also aided by some other field assistance, worked and conducted detailed ethnography in the five selected communities for the study which include Ndiowu, Nru, Ozzizza, Inyishi and Umudike. The major method of data collection were participant observation and in-depth interviews which involved 53 semi-structured interviews with selected informants from the study communities coupled with detailed field notes. Most of these interviews were conducted in 2012 and 2013, with some other informal discussions with some members from the five chosen communities in the study area. The average duration for each interview session was 25 minutes. The researchers visited these communities in many occasions and went round in each of these visits to observe the perceived impacts of the existing community development schemes and tourism projects in those communities. The outcome of these observation visits formed the nucleus of the discussion during interview sessions with the interviewees.

\section{Context and Background}

Southeast Nigeria which is one of the six geopolitical regions of Nigeria has numerous indigenous communities distributed unequally in the five states of the region, numbering about 760 in number; with $16,381,729$ human population collectively judging from the 2006 Population Census of the Federal Republic of Nigeria. Cluster and purposive sampling 
techniques aided in the sampling of the five communities from the study area. Each community was sampled in one of the states with concentration on communities with issues on perceived impacts of community development schemes and tourism projects. The sampled communities include Nru (Enugu State), Inyishi (Imo State), Ozzizza (Ebonyi State), Ndiowu (Anambra State) and Umudike (Abia State) (see Figure 1). These communities which were not classified amongst the urban areas have $65 \%$ of inhabitants with farming and other indigenous sources of livelihood, as their major economic activities. Nru and Umudike communities have equally civil service jobs owing to the presence of higher institutions within their vicinities. Ozzizza was the least developed as at the time of this research. The major community development schemes that were found in those communities include pipe born water, market facilities, modern road networks, community schools, cooperative societies, community/village assembly meeting halls, scholarship schemes, agricultural facilities, transportation facilities, tricycle transportation schemes, etc. $45 \%$ of these schemes were donated by the various tiers of the government (i.e. Federal, State and Local governments), 30\% by the community efforts through Felt-Need initiatives, 15\% from individuals and organised groups from those communities, and finally 10\% from NGOs and other philanthropists or politicians from outside these communities. On the part of tourism projects, most of these communities have much tourism potentialities that are still lying unharnessed, the major problem being perceived impacts from developed tourism projects in the host community. For instance there are organised festivals like the Ikeji, New Yam, Ahiajioku, etc, natural attractions like caves, streams, waterfalls, lakes, etc. They also have hotels, eateries, minor parks, bars, etc. Most of these their tourism potentialities are being denied meaningful tourism development owing to the hosts' perceived impacts. Apart from Nru and Umudike which can be classified as semi-rural, the other three communities are core rural communities. One of the major economic challenges of these communities is that a greater percentage of their workforce constantly engages in rural-urban migration leaving the economic structure of the communities in the weak hands of the aged and children except the Nru and Umudike communities (owing to the presence of mixed life style as noted earlier). Distance and funding were amongst the major limitations to the research process.

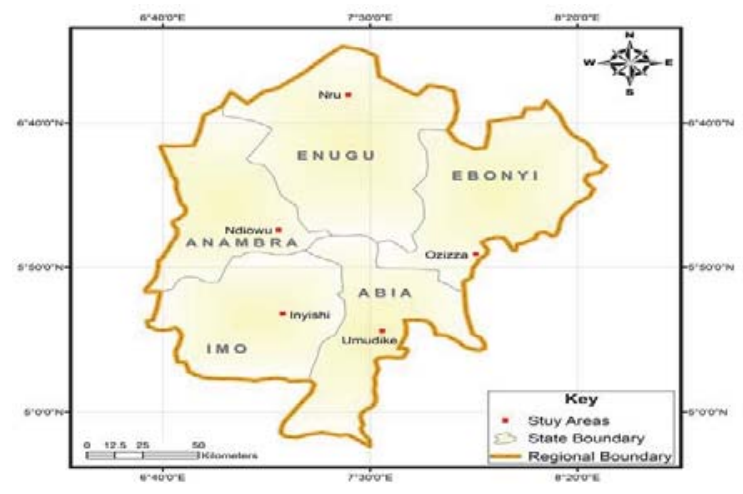

Figure 1: Map of Southeast Nigeria showing the five sampled Communities.

Source: Fieldwork, 2012

\section{Previous Studies}

There are some previous studies that have looked at the opportunities of community development schemes and tourism development in the rural communities. For instance, Anyanwu (1992) is of the opinion that community development schemes are amongst the instruments that can be used to improve the living standard of those living in the rural areas. $\mathrm{He}$ also noted that the use of untrained community development officers would deprive a given community the opportunities of harnessing the potentialities of community development schemes in rural areas. He went further to warn that such schemes can only be successful when handled by a professional in community development. Ezeh (1999) noted that community development in rural communities' aids in enhancing the economic opportunities of those living in rural areas. He concluded that for community development schemes to be successful in a given rural area, six principal phases should be followed in the process. These phases include; exploratory, organisational, discussion, action, new project and continuation phases. Also, Habib in his study attributed the major challenge to community development programmes in Pakistan to adult illiteracy. He asserted that "one of the indicators of Pakistan's poor performance in social 
development, relative to its state of economic development and to that of its neighbours, is the persistent high rate of adult illiteracy-54\% among males and 79\% among females" (Habib 1999:149). Hopkins (1995) is of the opinion that before community development initiatives would have much expected outcomes in Wales, United Kingdom, it should be guided by four basic elements; a comparative view of community's needs; action focused on critical social needs sectors; development experience and technical skills to make strategic interventions; and advocacy skills and political awareness. He concluded by noting that an articulate use of these elements would improve the living standard of those in the rural areas through community development initiatives. Harrison et al. concluded their work on race, ethnicity and community development by informing that "our case studies revealed that community development work is often most effective. It is most visible -working about the estate, chatting and befriending new residents or users of a centre, sorting out conflicts, providing individuals with support and encouragement" (Harrison et al. 1995:156-157).

However, some authors are of the opinion that most community development schemes in the rural communities have serious threats from the negative attitude of the host community (as a result of perceived threats). These studies further advocated effective community participation and involvement in community development programmes in their areas at both planning and implementation stages of the project (Abbott 1995; Hayton 1995; O'Neill 1995; and Berkeley Goodall, Noon and Collis 1995). Imhabekhai (2009) in his studies discovered that amongst impediments or challenges to successful community development schemes in rural areas are crisis in the community. He informed that a crisis-prone community would not harness the potentialities of community development schemes in rural communities. Moreover, Yinbun (1995) in his work on community mobilisation and health care in rural China noted that adult illiteracy has been a major impediment to community development programmes in the rural China mostly in the area of rural health. He concluded his studies in the following lines "for the sake of sustainable health development in rural China, the Chinese agencies concerned and development agencies of the international community should attach more importance to both these formal and informal aspects of human resource development" (Yin-bun 1995:325).

On tourism projects, Nwankwo and Anozie (2013) were of the opinion that tourism projects improve the socioeconomic development of Ndiowu Community in Anambra State. They went further to state that articulate sustainable planning process would guarantee successful tourism development at rural areas. Oladele (1996) sees tourism projects as one of the useful instruments for improving the lives of those in the rural areas. He asserts that "unlike other industrial projects which benefits only the wealthy investors, tourism on the other hand has the capacity to trickle down and benefit a large grassroots population who can profitably share in the proceeds of vacation and travel industry through income multiplier effect" (Oladele 1996:11). Ogundele (2001) was of the opinion that tourism projects should be encouraged even more at the grassroots (rural areas) for meaningful development that would amongst other things discourage rural-urban migration in Nigeria. He also pointed out that both public and private sectors of the economy have great roles to play in ensuring sustainable tourism projects at the grassroots.

Nwankwo and Agboeze (2014) suggested various community development approaches that are aimed at eliminating various challenges of tourism projects in the rural areas. These approaches include; matching grant approach, the sectoral approach, integrated approach, partnership approach, community schools approach, and directive approach. These approaches are aimed at ensuring a sustainable tourism projects at rural areas. Finally, Agboeze and Nwankwo (2013) in their study on community development principles in rural communities were of the opinion that community development initiatives have the potentialities of improving the living standard of those living in the rural communities. They informed that articulate use of community development principles would help in managing the various challenges of community development in the rural areas. They however listed the following community development principles; the principle of self help, principle of felt need, principle of citizen participation, principle of self growth, principle self reliance, and principle of self direction.

These studies have helped in informing the positive potentialities of community development schemes and tourism projects in indigenous communities. They also looked at some of the various challenges to that effect and possible solutions in different parts of the world. This current study studied the various challenges and opportunities of community development schemes and tourism projects in the selected communities from the study area; but more importantly the hosts' perception of impacts from these projects, hence this host perception of impacts form one of the basic challenges of community development schemes and tourism projects in the study area.

\section{Hosts' Perceived Impacts from Community Development Schemes and Tourism Projects}

Rural communities' developers and other experts have remained resolute in their insistence on the role of community development schemes and tourism projects to meaningful development and better lifestyle at rural areas. Although their insistence and other necessary efforts may not be jettisoned, but questions will still be asked on the sustainability of these 
projects in the midst of perceived impacts from the hosts. Although impacts can be viewed from both positive and negative dimensions, the focus of this research is on the negative impacts as perceived by the hosts. These hosts' perception of impacts is viewed from two angles; perception-as-conceived and perception-as-observed. The perceptionas-conceived has to do with those impacts that are perceived as future antecedents of proposed community development schemes or tourism projects in a particular community. Source of such impact perceptions could be from experiences of neighbouring communities, other externals' experiences or imposed convictions from within and/or outside the community. Perception-as-observed on the other hand has to do with hosts' perceived impacts from existing community development schemes or tourism projects. This could be as a result of negative antecedents of existing projects as experienced by the host. A detailed ethnography conducted during the research revealed some major perceived impacts of existing community development schemes and tourism projects in the sampled communities. Emphases were given to results that were more valid, verifiable and transferable from the field.

\subsection{Depletion of heritage resources}

Nwankwo (2013) categorized heritage resources into two broad categories of tangible and intangible heritage resources. Tangible include those heritage resources that can be touched or felt such as caves, architecture, water bodies (ie waterfalls, streams, rivers, lakes, etc), traditional objects of worship (i.e. traditional clay pots at shrines, masks, symbol of authority, drums, sacred trees, sacred groves, etc), etc. Intangible heritage resources refer to climate, language, belief system, value system, folklores, myths, indigenous habits, etc. Africans generally have great respect for their indigenous cultures and value system and would prefer not to tolerate existence of any initiative in their communities that pose possible threats to these aspects of their lives. Heritage resources and their values have formed the basis for the existence of most African states no thanks to the communal lifestyle that is still inherent in most parts of Africa. This scenario was not different from the study area of the research, the Southeast Nigeria. Nru, Umudike, Inyishi, Ndiowu and Ozzizza communities in Southeast Nigeria still held tenaciously their traditional values and would not undermine any perceived impacts on any of them. They have the view that most of these community development schemes and tourism projects have the tendencies of depleting their much valued heritage resources which have been generationally transferred from inception. One of the family heads in Ndiowu community clearly noted that;

We are afraid of restructuring of our traditional market (Orie market) through a community development scheme. This is because that market has some traditional values and also serves as meeting points with our ancestors. It has religious significance to the community hence one of the greatest shrines in the history of the community (Ebeagwu deity) was sited there in the past. The perceive effects from comprehensive restructuring of this traditional market has denied this market of meaningful community development schemes in the past (Alexander Amazu, Interview, Ndiowu, September 4, 2012.

Such was also the case at Inyishi in Imo state where it was stated that community development schemes has devastated the religious values of Umuosu-Oburu shrine which used to be renowned in the community. One of the daughters of Inyishi community who had already married outside the community informed that;

The case and condition of Umuosu-Oburu deity in Inyishi has made the traditional custodians of the community to develope wrong perception of community development schemes when it has to do with any of the heritage resources of the community being tampered with (Ogechi Emeka, Interview, Inyishi, July 24, 2013).

One of the informants categorically noted that they rejected to be given borehole by the government due to the fact that the chosen site for the project is their old masquerade house which has been in existence since time immemorial. Another informant noted that they rejected meaningful development initiatives at the waterfall in Ezeagu (See Figure 3) due to the fear of losing the socio-religious values of the waterfall to the community. Most of these communities prefer sustaining their heritage values inherited from their forefathers and handing them over to their children, than accepting any development that inflict generational injuries on their heritage resources. Although some enlightened members of the group share different opinions to this by insisting that community development schemes and tourism projects would bring even development of their communities. But most of these set of people who share this second opinion live in the urban areas and are always seen around their communities during special occasions. The people who perceive these projects as threats to their heritage resources reside in the village and form the major stakeholder for projects going on in their various communities.

\subsection{Perception of impacts as death ensnare}

Africans value human blood, hence it is a taboo to kill or shed blood. Death is seen as the last resort of fate to avenge 
human boob. This is why issues that have gone beyond human are left fate final action. Any man who kills is perceived as an evil and hence cannot live communally with other members of the kindred if discovered. Some of the community development projects are perceived as death traps for the members of these communities. For instance an interaction with some members of Ozizza community revealed that they perceived tarred roads in the hinterlands of the community as death traps and hence should be resisted. This view was equally perceived at Ndiowu community where their own is coming as perception-as-observed impacts. At Inyishi, some members of the community refused using provided pipe born water by insisting that their life is at risk. Instead they hold tenaciously their belief on the use of their traditional stream known as lyi-amukwu as their major source of water in the community. An informant at Ozzizza informed that for the sake of human life, they would prefer using their local stream as their major source of drinking water. Same is applicable with lyi-Ikpa at Ndiowu which many prefer using as source of drinking water than the provided modern source of water in the community. Also Tricycle transport scheme and other transportation schemes are perceived as threats to human life owing to the possibility of fatal accident. Many have refused this scheme for the fear of imminent accident. The death of one person can cause a total abandonment of a given project in a community.

\subsection{Traditional land tenure system}

There is also a perceived impact on the traditional land tenure system which is making it almost impossible to have adequate land mass for community development schemes and tourism projects. Lands are owned on the individual basis with few existing communal lands being demarcated and allotted to the members of the kindred. For instance, health centers that need a good land mass might not be able to be developed owing to the fact that the required land mass may not have been owned by an individual. People have perceived that projects that require much land mass would tamper with individual lands. Because of this they would frustrate such projects at the initial stage to discourage it. An informant at Nru in Enugu state noted that;

Our fore fathers made some grievous mistakes in the past to have allowed the University of Nigeria to be sited in Nsukka, taking a large chunk of the Nsukka land mass. Now, we there children do not have enough land mass to leave in. Most of us bought plots of land in our villages, just to build our family houses.

Also some roads at the hinterlands of these rural communities more especially at Ozzizza, Ndiowu and Inyishi, are track roads that are chocked-up by individual farm lands. Any attempt to grade such roads for them to be tarred, would be resisted by those people owing plots of land around these track roads. A typical example was observed at Ndiowu and Umudike communities where some parts of the communities have been lying bushy owing to lack of pliable roads automobiles as a result of people's refusal to allow their plots of land to be tampered with in the process of modern road networking. This last perceived impacts have left some sites like Ago-dike in Ndiowu in deplorable and abandoned state owing to pore accessibility. This particular site has approximately 450 plots of land.

\subsection{Tourist/visitor behavior}

Most tourists/visitors behave like children not necessarily out of wickedness or hatred on their hosts but the joy of strange experience. Most of the studied communities affirmed that they oppose tourism projects owing to perceived wrong attitudinal behavior of tourists/visitors who might have visited the community due to the tourism projects. They are afraid that strange visitors can cause havoc to their traditional values and may likely exert negative influence on their youths. This was the case with Ndiowu and Inyishi who perceive tourism projects as a beehive of social ills in the name of tourism and hence should be avoided to save the community from alteration and neglect of their traditional values. In some of the communities visited, informants were giving negative interpretations to tourists' behavior and other visitors to their community who were attracted to their communities by tourism projects. They concluded their judgments based on previous experience. This made some of them to see no reason for the existence of such development initiatives in their communities. Such negative attitudes towards tourists or other visitors can stimulate hostilities between members of the host community and tourists/visitors. Another informant from Ndiowu noted that;

During the last Ikeji festival (2011) in the Ndiowu community, the community witnessed a high rate of crime. The community vigilante later informed that most of those criminal and other unlawful activities were perpetuated by their visitors who visited them to enjoy the Ikeji and Okponsi festivals. This attitude affected the festival in the following year, hence many people failed to participate and there was a serious debate in the Chief's Cabinet on whether to scrape off the festival or not (Ogbuefi Onwuka, Interview, Ndiowu, March 21, 2012).

Sometimes some visitors only appreciate tourist attraction in a place without having a single regard for the host. Such visitors are always aggressive with the hosts and they may likely fight each other on slightest provocation. The 
informant from Umudike affirmed that unnecessary hostilities have made the community to ban tourists from visiting some of their heritage resources.

\subsection{Perceived threats on the community's carrying capacity}

Community's carrying capacity is the limit of visitors a particular community could carry owing to the presence of community development schemes and tourism projects. For instance a health centre of 20 bed spaces can be threatened by overcrowding, may be during irregular occasions. Also in some tourism projects initiatives like museums, a particular number of people is required inside the museum at a time. Such is also the case with a given community which tends to be over crowded during some tourism projects initiatives like festivals, etc, or community development projects like enlightenment campaigns, educational facilities, cooperative facilities, etc. Such situations cause much harm than good to the carrying capacity of such communities. It could result to shortage of food supply, inflation, destruction of farm lands, unnecessary defecations on streets and farmlands, shortage of power and water supply, increased criminal activities, dilapidation of indigenous values, etc. Such situations have made the hosts over the time to begin to question the rationality of the existence of community development schemes and tourism projects in the rural areas. On this particular perceived impact, one of the respondents from Inyishi noted that;

Sometimes we resist community development schemes like modern markets, huge cooperative facilities, comprehensive road network, etc, and tourism related projects like hotels, bars, amusement parks, etc, due to the perceived unbearable impacts from huge presence of visitors as a result of the presence of such projects in our community. For instance we have limited source of water, limited food facilities in circulation, limited medical and educational facilities, and even money in circulation. Huge presence of visitors could cause us lose some of these or even make them to be more expensive due to too much demand. More importantly increase in the cost of food materials as a result of food shortage owing to excess demand, would bring an untold hardship in our community (Chidi Amadi, Interview, Inyishi, October 8, 2013).

No matter the great contributions of community development schemes and tourism projects to socio-economic development of rural areas, these hosts still perceive these projects as threats to their lives in their various communities. Some of the respondents informed that they will be more comfortable with some of these projects that have direct benefits to their community like minimal health and educational facilities that do not have the tendency of attracting great number of outsiders to their community. For this perceived impact, they appreciate the role of community development schemes and tourism projects in community building but they grimace at the much presence of such projects so as not to attract much number of visitors to their communities.

\section{Results of Perceived Impacts of Community Development Schemes and Tourism Projects}

Having seen the major perceived impacts as discovered during ethnographic studies, it will be erroneous for someone to believe that these rural communities would accept imposition of community development schemes and tourism projects without further and detailed consultations, clarifications, collaborations and collective acceptance. This is owing to the fact that they view these projects differently from the dimension of experts or other economists. During interview sessions, many of them revealed the possible results of imposed development projects and even the outcome of such projects in some communities where they were forced on the people in the past. First and foremost is the act of Xenophobism. This is a natural hatred or dislike towards tourists or visitors without cogent or understandable reasons, by their hosts. Naturally, some people in the rural areas had developed hatred on tourists/visitors in their localities and would always feel disgusted at the sight of tourists/visitors. They always perpetuate all kinds of antagonisms just to ward off possible existence of tourists/visitors in their areas. Such attitudes discourage tourists/visitors from using such places which invariably would discourage both public and private investments at such communities. Although such was not the case at some of the rural areas visited in the course of this study, but some of the informants noted that such was the case in their areas in the past and still exists in some other communities in the rural areas of the developing nations. Sometimes the village youths are mobilised to word off visitors/tourists to their communities, who visited for holidays, see attractions or benefit from the existing community development schemes at such communities. Use of community/village youths for such assignments is more pronounced at Inyishi, Ndiowu, Umudike and Ozzizza communities visited in the course of the study. These village youths pose great resistance to such visits to their community. For instance a village youth leader at Obimo in Nsukka area of Enugu state pointed out that;

We do not resist visitors on our own as village youths, but we act on the directives of our leaders and elders who will always alert us at the sight of suspicious presence of huge number of visitors. We do this to protect our community 
against defilement from unrecognized outsiders. We advise that our leaders and elders should be informed and convinced of any relevant development projects before their execution in our community to avoid unnecessary hostilities from the members of our community against such projects or visitors to our communities as a result of the presence of such projects (Richard Ugwoke, Interview, Obimo, May 18, 2014).

Moreover, another resultant effect is the issue of necessary and unnecessary demonstrations and agitations. It was understood that in the most rural areas, community development projects and tourism projects are targets during peaceful or destructive demonstrations in an attempt to make a particular demand or interest known to the government (Abbott 1995). These agitations are never ending at rural areas as they would always feel marginalized and not in the government's programme for development as was noted by an informant. Such attitude had completely destroyed or damaged these projects that were developed at such rural areas. When a particular project is wrongly perceived as having negative effects, these hosts insisted that it is even neglect on their human rights as Nigerians to site such projects in their communities against their wishes (Butler 2009).

And that they can agitate to the extent of damaging those projects to make their request known. An Informant at Inyishi informed that they can even threaten the governments on those projects when making a different request from the government; using these projects as a bet with the government. This is one of the reasons why governments and other donors are always discouraged to invest largely on these developmental projects at the rural areas. Instead, they prefer to continue investing on such projects at the urban areas which negatively contribute to rural-urban migration. An Informant at Nru advised that his attitude can be checked through strategically positioning and securing of these projects, coupled with adequate orientation and involvement of members of the host communities in such developmental projects (Ukaegbu \& Agunwamba 1995). In addition, these wrong perceptions of community development schemes and tourism projects in the rural areas by host communities would cause a delayed socio-economic development in the rural areas hence developers of such projects are discouraged from making wasteful investments. These investors (both public and private) have resorted to investing in the urban areas where the security and durability of such projects is more guaranteed. This has left most of these rural communities like Ozzizza, Ndiowu, and Inyishi devastated in terms of meaningful socio-economic development. For instance the perception of negative effects of presence of a higher institution at Ndiowu community, made the community to reject the locating of a Pre-diploma programme of the Federal Polytechnic Okoh in Agbata village of Ndiowu. The programme was later moved to Ufuma, a neighbouring community. After ten years this particular project has boosted the socio-economic development of Ufuma community ahead of Ndiowu community who still lack meaningful socio-economic development as at December 2014. Also of the great observation is the state of great tourism potentialities that have been abused and abandoned in the investigated communities owing to the perceived negative impacts. For instance some host communities like Ndiowu have undermined meaninful tourism development and promotion on the famous Ikeji and Okponsi Festivals in the community. They denied these festivals meaningful tourism promotions due to fear of possible diffusion of western culture in the cultural lives of the people. Also, there are great shrines and sacred groves in some of the investigated communities like Umudike, Inyishi, and Ozzizza that could have served as great tourist attractions in those communities but were limited owing to perceived impacts on the traditional values of the people. Besides, Ozzizza community has an astonishing cluster of ten rock-overhangs at the farming site of the community. They conceived this site as a sacred site that should not be tempered with in the name of tourism promotion and development. This was also the case at Ezeagu in Enugu State, where great tourism potentialities like Water fall (see Figure 2 below) has been denied meaningful tourism development as a result of hosts' perceived impacts. These attractions at Ezeagu have the potentialities of making the community a beehive of tourists' activities when sustainably developed.

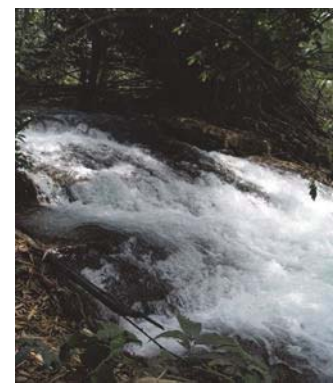

Figure 2: This Waterfall is one of the major heritage tourism attractions at Ezeagu Tourist Complex that are still abandoned as a result of hosts' perception of impacts. 


\section{Conclusion}

Previous literatures revealed the relevance of community development schemes and tourism projects to sustainable lifestyles of those living in the rural areas (Aguilo and Rosello 2005; Besculides et al. 2002; Garrod and Fyall 2000; Poria and Ashworth 2009; Johnson et al. 1994; Winter 2008; etc). Despite this, these projects have been posed with varying degrees of obstacle owing to the perceived negative impacts by the host communities. And this issue needed to be addressed since it will enable for the utmost maximization of the benefits of community development scheme and tourism projects in the development of rural communities in Nigeria and some other developing nations. How then can this problem be addressed? Some of the enlightened informants from the investigated communities informed that there is a wide gap between the proponents of such projects and the host communities. For instance an informant from Ndiowu noted that;

Causes of these perceived negative impacts on development projects in the rural communities like our community Ndiowu include poor orientation, non involvement of members of the host community during project planning, implementation and management, inadequate stakeholders' consultation, poor management skills on the part of developers, disregard for indigenous value system and other heritage resources.

That notwithstanding, sustainable tourism development initiative is aimed at developing, packaging and promoting various tourism resources of a people for socio-economic and cultural gains (Oladele 1996; Ogundele 2001; Nwankwo \& Agboeze 2014). Such initiatives also aim at the preservation and sustenance of these tourism resources of a people. Observations made revealed that most members of these host communities do not have adequate understanding of the reasons for the existence of such development projects in their communities. However, considering the nature and relevance of development projects in the rural economies, it is imperative that successful and sustainable development project designs should take into consideration some factors which include adequate stakeholders' consultation and involvement, proper orientation programmes for the host communities and their visitors, community involvement in project development and management, use of experts and relevant developers, ensuring harmonious relationship between development projects and members of host communities (Jimura 2011; Hayton 1995; Besculides et al. 2002; Nwankwo and Anozie 2013). Consideration of these factors will not only aid in the sustainability of these projects but equally encourage public and private investments in community development schemes and tourism projects in the rural areas. Also, the principle of felt-need should not be jettisoned in planning of community development schemes hence it will encourage the concept of development from within at the rural areas (Eze 1990). This concept entails harnessing opportunities from the environment for meaningful development and sustainable lifestyles for people in that particular environment. It aided the people from the rural part of Istanbul-Turkey after the 2009 earthquake and subsequent government delay in supplying needed relief materials (Maruyama 2008).

\section{References}

Abbott, J. 1995. "Community Participation and it Relationship to Community Development" Community Development Journal: An International Forum 30 (1): 158-168.

Abiona, A.I. 2009. Principles and Practice of Community Development. Ibadan: Ibadan University Press.

Agboeze, M.U and Nwankwo, E.A. 2013. "Indigenous Communities and Community Development Principles in South-East Nigeria: Challenges and Prospects" Developing Country Studies 13(10): 85-93.

Agbor, U.I. 2013. "Local Governance and Regional Crises in Nigeria: Rethinking Governance dimensions to the Crisis in the Niger-Delta Region" Developing Country Studies 3(10): 78-84.

Aguilo, S. and Rosello J. 2005. "Host Community Perceptions: A Cluster Analysis" Annals of Tourism Research 32(4): $925-941$.

Anyanwu, C. N. 1992. Community Development: The Nigerian Perspective. Ibadan: Gabesther Educational Publishers.

Berkeley, N., Goodall, G., Noon, D. and Collis, C. 1995. "Involving the Community in Plan Preparation" Community Development Journal: An International Forum 30 (1): 189-199.

Besculides, A. Lee, M. and McCormick, P. 2002. "Residents Perceptions of the Cultural Benefits of Tourism" Annals of Tourism Research 29(2): 303-319.

Butler, R. 2009. "Tourism in the Future: Circles, Waves or Wheels" Futures 41(1): 346-352.

Eboh, E.C. 1995. "Sustainable Development: for Theory and Implications for Rural Nigeria" In Rural Development in Nigeria: Concepts, Processes and Prospects, edited by Eric C Eboh, Chukwuemeka Okoye and Damian Ayichi, Enugu: Auto- Century publishing Company.

Eze, C.A. 1990. Theory and Practice of Community Development: An Introduction to Community Development. Enugu: Liberty Printing Press.

Ezeani, E. A. 1995. "National Planning and Rural Development in Nigeria" In Rural Development in Nigeria: Concepts, Processes and Prospects, edited by Eric C Eboh, Chukwuemeka Okoye and Damian Ayichi, Enugu: Auto- Century publishing Company. 
Garrod, B. and Fyall, A. 2000. "Managing Heritage Tourism" Annals of Tourism Research 27(3): 682-708.

Habib, N. 1999. "Community Development through Adult Education among Women" Adult Education and Development: 149-164.

Hampton, M. 2005. "Heritage, Local Communities and Development" Annals of Tourism Research 32(3): 735-759.

Harrison, L., Hoggett, P. And Jeffers, S. 1995. "Race, ethnicity and community Development" Community Development Journal: An International Forum 30 (1): 145-157.

Hayton, K. 1995. "Community Involvement in Economic Regeneration -Lessons from North East England" Community Development Journal: An International Forum 30 (1): 169-181

Hopkins, R. 1995. "Community Economic Development: A Question of Scale" Community Development Journal: An International Forum 30 (1): $48-55$.

Imhabekhai, C. J. 2009. Management of Community Development: Programmes and Projects. Benin: Uniben Press.

Jimura, T. 2011. "The Impact of World Heritage Site designation on Local Communities: A Case Study of Ogimachi, Shirakawa-Mura, Japan" Tourism Management 32(2): 288-296.

Johnson, J., Snepenger, D. and Akis, S. 1994. "Residents' Perceptions of Tourism Development" Annals of Tourism Research 21(3): $629-642$.

McKercher, Maruyama, H. 2008. "Non-formal Education for Sustainable Development in Turkey". Adult Education and Development. A publication of the Institut fur Internationale Zusammenarbeit des Deutschen Volkshochsscul-Verbandes, Geermany.

B. and du Cros, H. 2002. Cultural Tourism: The Partnership between Tourism and Cultural Heritage Management. New York: The Haworth Hospitality Press

Nwankwo, E.A. and Agboeze, M.U. 2014. "Community Development Approaches and Preservation of Heritage Resources in Igboland" Nsukka Journal of the Humanities 22:143-159

Nwankwo, E. and Anozie, O. 2013. "Sustainable Planning of Ndiowu: a Virgin Tourist Ecstasy" Ikenga: International Journal of Institute of African Studies 15 (1\&2): 305-325.

Oformata, G. E. K. and Okafor, F. C. 2002. "Tourist Resources" In A survey of the Igbo Nation edited by G. E. K. Oformata. Onitsha: Africana First Publishers Limited.

Ogundele, S. O. 2001. "Tourism Development in Nigeria: A Grassroots Perspective". In Cultural and Eco-Tourism Development in Nigeria: the Role of the Three Tiers of Government and the Private Sector, edited by David A. Aremu. Ibadan: Hope Publications.

Okonkwo, R. C. 1995. "Rural Electrification in Nigeria: Strategies and Problems" In Rural Development in Nigeria: Concepts, Processes and Prospects, edited by E. C. Eboh, C. U. Okoye and D. Ayichi. Enugu: Auto-Century Publishing Company.

Oladele, F. 1996. Understanding tourism in Nigeria. Ibadan: JIS Printing Press.

O'Neill, G. 1995. "The Social Construction of Economic Regeneration: An Examination of the Case of Derry" Community Development Journal: An International Forum 30 (1): 182-188

Osofoh, F.C and Agbonome, P.C. 2014. "Revitalization and Sustainability of Ecotourism in Nigeria through Conservation, Mass Education and Participation" Nsukka Journal of the Humanities 22: 325-348.

Poria, Y., and Ashworth, G. 2009. "Heritage Tourism - Current Resources for Conflict" Annals of Tourism Research 36(3): 522-525.

Silva, L. 2014. "The two opposing Impacts of Heritage Making on Local Communities: Residents' Perceptions: A Portuguese Case". International Journal of Heritage Studies 2(6): 616-633.

Ukaegbu,C.C. and Agunwamba, C.C. 1995. "Conflict and Consensus in Rural Development: The Neglected Dimension". In Rural Development in Nigeria: Concepts Processes and Prospects, edited by E.C. Eboh, C.U. Okoye and D. Ayichi. Enugu: Autocentury publishing company.

Winter, T. 2008. "Post-Conflict Heritage and Tourism in Cambodia: The burden of Angkor" International Journal of Heritage Studies 14(6): 524-539.

Yin-bun, C. 1995. "Community Mobilization and Healthcare in Rural China". Community Development Journal: An International Forum 30 (1): $317-326$ 